\title{
KILAT
}

Vol. 10, No. 1, April 2021, P-ISSN 2089-1245, E-ISSN 2655-4925

DOI: https://doi.org/10.33322/kilat.v10i1.1178

\section{Perbandingan Efisiensi Turbin Uap Kondisi Aktual Berbasis Data Komissioning Sesuai Standard ASME PTC 6}

\author{
Agus Noor Sidiq ${ }^{1}$; Muhammad Anwar ${ }^{2}$ \\ ${ }^{1}$ PLN UPDL Suralaya Indonesia \\ ${ }^{2}$ PLN UPK Tarahan Indonesia \\ ${ }^{1}$ agus.ns@pln.co.id
}

\begin{abstract}
The performance of steam turbine is very important to know and analyze to understand the actual condition compared to conditions of commissioning. The purpose of this paper is to understand the performance by comparing the efficiency of the steam turbine in actual conditions based on commissioning data in accordance with ASME PTC 6 rules. By doing this, it can be known the actual performance experienced by the steam turbine, the actual condition is what will be compared with the commissioning data so that later will be obtained performance differences that will be a concern in the continuous improvement of the steam turbine. The observations were made at Tarahan Power Plant Unit 3 regarding the condition of steam entering the turbine in this case the pressure and temperature, the condition of the extraction steam, and the condition of the exhaust side that will affect the performance analysis of the steam turbine.
\end{abstract}

Keywords: Commissioning, ASME PTC 6, Steam Turbine, Efficiency

\begin{abstract}
ABSTRAK
Performa turbin uap merupakan suatu hal yang sangat penting untuk diketahui dan dianalisa untuk memahami kondisi aktual dibandingkan kondisi saat komissioning. Tujuan paper ini adalah untuk memahami performa dengan melakukan perbandingan efisiensi turbin uap kondisi aktual berbasis data komissioning sesuai dengan kaidah ASME PTC 6. Dengan melakukan hal ini maka dapat diketahui performa aktual yang dialami oleh turbin uap tersebut, kondisi aktual inilah yang akan dibandingkan dengan data-data kommissioning sehingga nanti akan didapatkan selisih performa yang akan menjadi perhatian dalam perbaikan berkelanjutan pada turbin uap tersebut. Hasil pengamatan dilakukan pada PLTU Tarahan Unit 3 mengenai kondisi uap yang masuk ke turbin dalam hal ini tekanan dan temperaturnya, kondisi uap ektraksi dan kondisi sisi exhaust yang akan mempengaruhi hasil analisa performa turbin uap tersebut.
\end{abstract}

Kata kunci: Komissioning, ASME PTC 6, Turbin Uap, Efisiensi 


\section{PENDAHULUAN}

Sebelum membahas tentang performa turbin uap yang lebih detil maka lebih dahulu dijelaskan mengenai siklus proses uap-air pada pembangkit listrik tenaga uap. Secara sederhana gambar 1 adalah suatu diagram T-s yang merupakan siklus rankine yang digunakan untuk menggambarkan suatu proses dalam pembangkit listrik tenaga uap tanpa adanya reheater seperti pada proses yang terjadi di PLTU Tarahan.

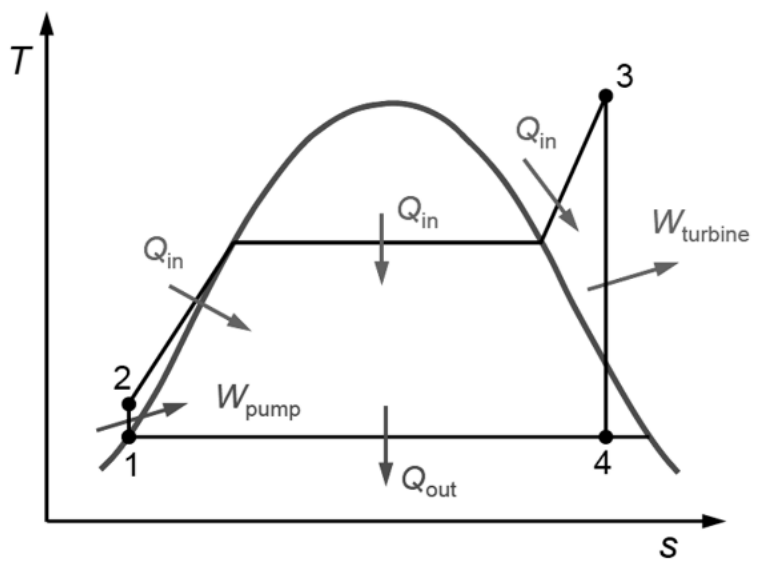

Gambar 1. Diagram T-s PLTU tanpa reheater

Dari gambar 1 tersebut dapat dijelaskan bahwa lingkup pekerjaan pengujian performa turbin hanya pada siklus turbin yang terlibat yaitu $3-4-1-2$, sedangkan siklus $2-3$ tidak termasuk karena termasuk siklus boiler. Tujuan pengujian performa turbin uap adalah untuk menentukan daya keluar dan tara kalor turbin serta efisiesi turbin uap. Membandingkan performa turbin uap saat ini dengan performa saat dilakukan komissioning merupakan hal yang penting dilakukan agar kita bisa mengetahui penurunan performa yang terjadi serta untuk membuat mitigasi penanganan agar performa turbin uap bisa kembali seperti saat komissioning. Pada kesempatan yang lain hasil analisa performa turbin uap ini juga dapat menunjukkan hasil pencapaian dilakukannya kegiatan overhaul turbin sehingga dapat menunjukkan efektivitas perbaikan yang telah dilakukan. Secara umum yang dimaksud efisiensi turbin adalah kemampuan turbin untuk merubah energi panas yang dikandung uap menjadi energi mekanik untuk menggerakkan generator. Perhitungan performa turbin uap tergantung pada banyak faktor, termasuk susunan sudu-sudu turbin, kondisi uap masuk dan keluar turbin. Selain itu kinerja dari sebuah turbin uap sangat dipengaruhi oleh komponen lintasan uap, kondisi valve-valve governor, saluran masuk dan keluar turbin, sudu diam dan gerak, dan juga peralatan kendali kebocoran turbin uap. Perbandingan kerja yang dihasilkan turbin pada kondisi ideal (isentropis) dan kerja turbin aktual dapat digambarkan dalam diagram h-s (entalphy vs entropy) seperti pada gambar 2. Untuk memaksimalkan efisiensi turbin uap, rugi-rugi (losses) aerodinamika dan kebocoran uap pada lintasan uap di turbin harus diminimalkan, baik pada komponen berputar (rotor, shaft) maupun diam (stationary). Daya yang dihasilkan dari pembangkit listrik tenaga uap tergantung pada penurunan enthalpy dan laju aliran uap yang merupakan parameter utama untuk menentukan beban suatu pembangkit [1]. Meskipun jumlah enthalpy spesifik meningkat, daya yang dihasilkan menurun karena penurunan laju aliran dengan variasi untuk beban pada turbin tekanan tinggi. 


\section{KILAT}

Vol. 10, No. 1, April 2021, P-ISSN 2089-1245, E-ISSN 2655-4925

DOI: https://doi.org/10.33322/kilat.v10i1.1178

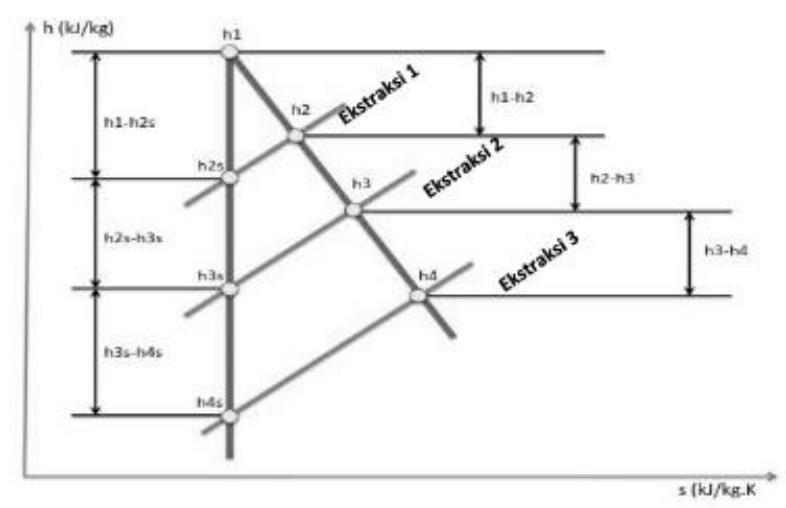

Gambar 2. Diagram h-s Kerja turbin ideal vs aktual

Perhitungan yang terlibat dalam efisiensi turbin uap dihitung sesuai persamaan [1]

$W_{\text {ta }}=\left(h_{\text {in }}-h_{\text {out }}\right)$

(1)

$P=\dot{m} W_{t a}$

(2)

$\eta_{i}=\frac{\text { kerja turbin aktual }}{\text { kerja turbin ideal }}=\frac{h_{\text {in }}-h_{\text {out }}}{h_{\text {in }}-h_{\text {out.s }}}$

(3)

$\eta_{t=\frac{W_{\text {net }}}{Q_{\text {in }}}}$

(4)

Keterangan :

$\mathrm{W}_{\mathrm{ta}}$ : kerja aktual turbin $(\mathrm{kJ} / \mathrm{kg})$

$\mathrm{h}_{\text {in }}$ : entalpi masuk turbin $(\mathrm{kJ} / \mathrm{kg})$

$\mathrm{h}_{\text {out }}$ : entalpi keluar turbin aktual $(\mathrm{kJ} / \mathrm{kg})$

$\mathrm{h}_{\text {out.s }}$ : entalpi keluar turbin ideal $(\mathrm{kJ} / \mathrm{kg})$

$\mathrm{P}$ : daya aktual turbin $(\mathrm{kW})$

$\dot{m}$ : laju uap masuk turbin $(\mathrm{kg} / \mathrm{s})$

$\eta_{i}$ : efisiensi isentropis turbin uap (\%)

$\eta_{\mathrm{t}}$ : efisiensi thermal $(\%)$

$\mathrm{W}_{\text {net }}$ : kerja turbin netto $(\mathrm{kJ} / \mathrm{kg})$

$\mathrm{Q}_{\text {in }}$ : panas input $(\mathrm{kJ} / \mathrm{kg})$

Turbin Uap (steam turbine) merupakan suatu penggerak mula yang mengubah energi potensial uap menjadi energi kinetik dan selanjutnya diubah menjadi energi mekanis dalam bentuk putaran poros turbin. Setiap turbin memiliki nilai efisiensi yang bebeda - beda, tergantung pada kondisi steam yang masuk ke turbin. Sedangkan kondisi steam tersebut dipengaruhi oleh faktor tekanan uap yang masuk ke turbin [2]. Dalam usaha meningkatkan efektivitas kerja yang dihasilkan dari sebuah pembangkit listrik, perlu adanya analisa untuk mengetahui besarnya kerja aktual dan ideal dari turbin. Efisiensi merupakan perbandingan kerja aktual yang dihasilkan dan kerja ideal dari turbin. Melalui analisa efisiensi ini dapat diketahui sebuah turbin masih beroperasi secara maksimal berdasarkan kerja aktual yang dihasilkan [3]. 


\section{METODE PENELITIAN}

Pembangkit listrik tenaga uap merupakan suatu pembangkit listrik dimana energi listrik dihasilkan oleh generator yang diputar oleh turbin uap yang memanfaatkan tekanan uap hasil penguapan air yang dipanaskan oleh bahan bakar di dalam ruang bakar (boiler). Salah satu komponen penting dalam PLTU adalah turbin uap. Turbin digunakan untuk memutar generator dengan cara mengubah energi termal yang terkandung dalam uap menjadi energi mekanik [4]. Perkembangan turbin uap untuk pembangkit listrik modern memberikan tinjauan otoritatif terhadap optimasi desain turbin uap, analisis dan pengukuran, pengembangan bilah turbin uap, dan komponen penting lainnya, termasuk retrofitting turbin dan turbin uap untuk pembangkit listrik terbarukan [5]. Untuk mengetahui performa efisiensi maupun kerugian-kerugian pada siklus pembangkit tenaga uap dapat menggunakan siklus rankine. Untuk mengetahui performa atau menghitung siklus rankine yaitu ada beberapa data yang harus diambil dibeberapa titik, antara lain data pressure dan temperature uap pada boiler, turbin, dan kondensor, kemudian data pressure dan temperature air pada turbin dan daya pompa (spesifik volume)[6].

Perhitungan performa turbin uap yang akan dikaji ini berdasarkan pengambilan data performance test pada PLTU Tarahan Unit 3 bulan Agustus 2020 pada beban 90 MW. Kondisi saat performance test adalah kondisi yang tidak selalu stabil oleh karena itu metode penelitian yang dilakukan adalah metode observasi dan pengelompokan sumber data yang diperlukan seperti kondisi dan pola produksi steam pada boiler, turbin dan mengidentifikasi data-data tersebut kemudian dilakukan perhitungan pada data yang ada [7]. Adapun metode penelitian yang digunakan adalah sesuai blok diagram pada gambar 3 di bawah ini. Pengambilan data performance test dilakukan selama 4 jam pada beban 90 MW. Data yang digunakan untuk perhitungan adalah data rata-rata yang diambil selama 4 jam tersebut. Adapun penyesuaian dan faktor koreksi yang diberikan tidak terlalu signifikan mengingat pelaksanaan performance test yang dilakukan sudah sesuai dengan kondisi ideal pengambilan data pada siklus tertutup suatu pembangkit listrik tenaga uap.

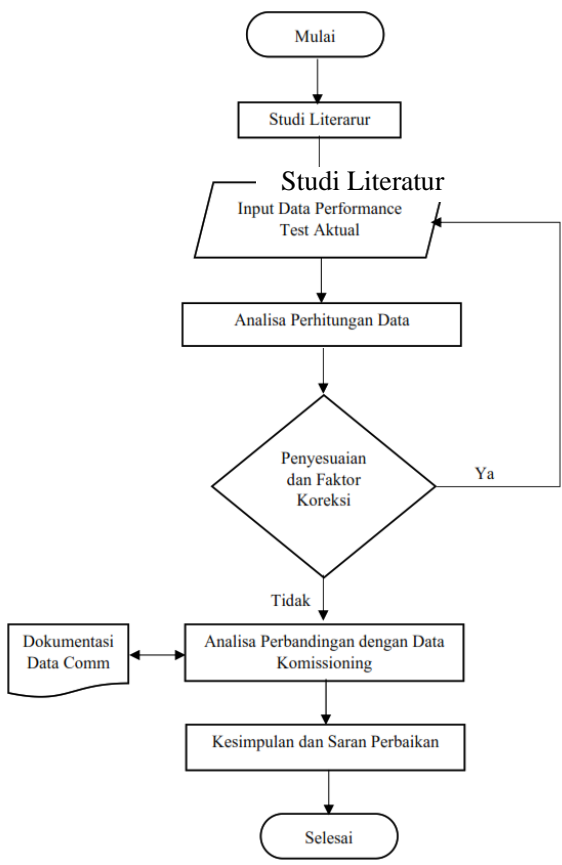

Gambar 3. Metode Penelitian 


\section{KILAT}

Vol. 10, No. 1, April 2021, P-ISSN 2089-1245, E-ISSN 2655-4925

DOI: https://doi.org/10.33322/kilat.v10i1.1178

Tabel 1 adalah inputan data hasil dari pengambilan data performance test pada beban $90 \mathrm{MW}$. Pengambilan data pada saat performance test mengikuti kaidah ASME PTC-6 [8] seperti ditunjukkan pada gambar 4 di bawah ini. Adapun data pada saat komissioning disajikan sebagai data pembanding yang akan menjadi landasan analisa dan pengambilan kesimpulan dan saran.

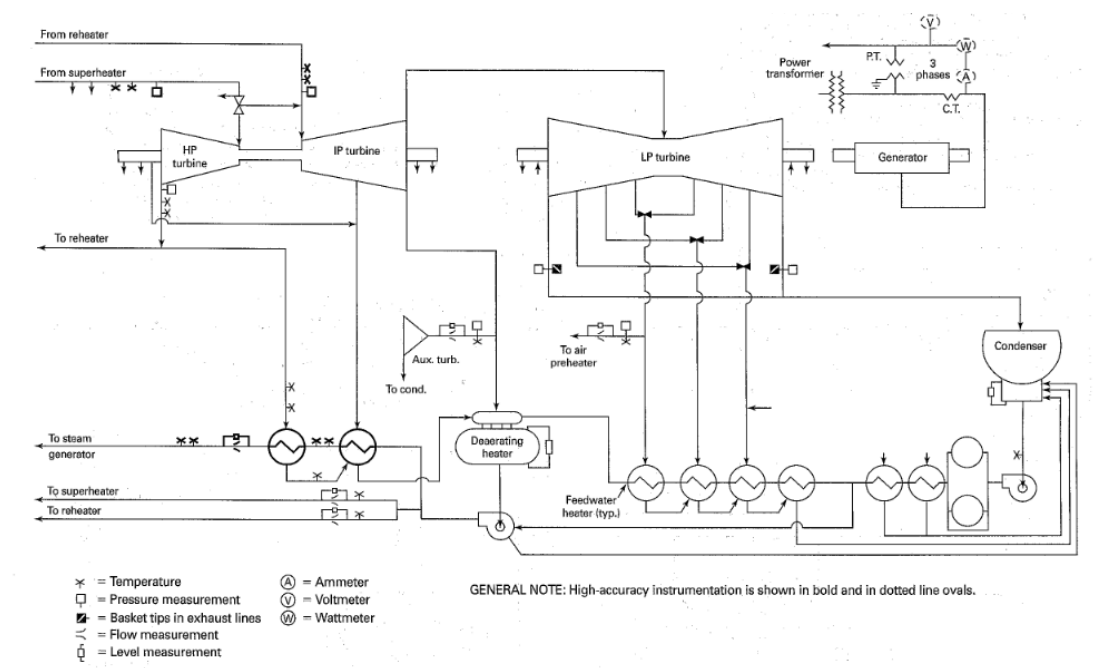

Gambar 4. Posisi Pengambilan Data Performance test sesuai ASME PTC 6 [8]

Efisiensi turbin uap pada dasarnya juga dapat dilihat dari energi panas yang dimasukkan untuk menghasilkan listrik sebesar $1 \mathrm{kwh}$ dan Turbine Heat Rate [9]. Pada dasarnya suatu perhitungan laju panas turbin menggunakan metode heat \& mass balance, efisiensi turbin diperoleh dengan membandingkan energi $1 \mathrm{~kW}$ dengan laju panas turbin dan mengalikannya dengan 100\% [10].

Tabel 1. Input Data Perhitungan

\begin{tabular}{|c|c|c|c|c|c|}
\hline \multirow{3}{*}{ No } & \multirow{3}{*}{ TAG No } & \multirow{3}{*}{ DESCRIPTION } & \multirow{3}{*}{ Unit } & PT Aktual & Commissioning \\
\hline & & & & $90 \mathrm{MW}$ & $\begin{array}{l}100 \mathrm{MW} \\
\text { (TMCR) }\end{array}$ \\
\hline & & & & 19-Aug-20 & 01-Dec-07 \\
\hline 1 & 3MKA10CE009XV1 & GEN ACTIVE POWER & MW & 90,30 & $100.775,20$ \\
\hline 2 & 3MKA10CE005XV1 & GEN VOLTAGE (W-U) & $\mathrm{V}$ & 11,15 & 6,31 \\
\hline 3 & 3MKA10CE003XV1 & GEN VOLTAGE (U-V) & $\mathrm{V}$ & 11,18 & - \\
\hline 4 & 3MKA10CE004XV1 & GEN VOLTAGE (V-W) & V & 11,19 & - \\
\hline 5 & 3MKA10CE006XV1 & GEN CURRENT (R) & A & $4.898,58$ & 5,40 \\
\hline 6 & 3MKA10CE007XV1 & GEN CURRENT (S) & A & $4.799,68$ & - \\
\hline 7 & 3MKA10CE008XV1 & GEN CURRENT (T) & A & $4.970,31$ & - \\
\hline 8 & 3MKA10CE012XV1 & GEN POWER FACTOR & - & 0,95 & 0,99 \\
\hline 9 & 3MKA10CE011XV1 & GEN FREQUENCY & $\mathrm{Hz}$ & 50,08 & 50,70 \\
\hline 10 & 3CBA10CE009XV1 & GEN FIELD VOLTAGE & $\mathrm{V}$ & 244,82 & 236,50 \\
\hline 11 & 3CBA10CE010XV1 & GEN FIELD CURRENT & A & 689,22 & 673,00 \\
\hline 12 & 3LCA30CF001XV1 & CONDENSER FLOW & $\mathrm{T} / \mathrm{h}$ & 321,10 & 294,45 \\
\hline 13 & 3LCA50CF001XV1 & U3-COND. FLOW / DEA INLET & $\mathrm{T} / \mathrm{h}$ & 341,46 & 287,73 \\
\hline 14 & 3HAC10CF001XV1 & ECO INLET FEEDWATER FLOW & $\mathrm{T} / \mathrm{h}$ & 333,88 & 336,97 \\
\hline 15 & 3LAE10CF001 & SH DESH \#1 SPRAY WATER FLOW & $\mathrm{T} / \mathrm{h}$ & 15,60 & 4,35 \\
\hline
\end{tabular}


KILAT

Vol. 10, No. 1, April 2021, P-ISSN 2089-1245, E-ISSN 2655-4925

DOI: https://doi.org/10.33322/kilat.v10i1.1178

\begin{tabular}{|c|c|c|c|c|c|}
\hline 16 & 3LAE20CF001 & SH DESUPERHTR \#2 SPRAYWATER & $\mathrm{T} / \mathrm{h}$ & 4,70 & 6,88 \\
\hline 17 & 3LBG10CF001 & HP AUX STEAM FLOW & $\mathrm{T} / \mathrm{h}$ & $6.490,04$ & 0,85 \\
\hline 18 & 3LCP62CF001XV1 & MAKE UP WATER FLOW & $\mathrm{T} / \mathrm{h}$ & 6,86 & 4,96 \\
\hline 19 & 0QP10CP001 & ATMOSPHERIC & $\mathrm{kg} / \mathrm{cm}^{2}$ & $1.005,27$ & $1.005,80$ \\
\hline 20 & 3LBA20CP010XV1 & $\begin{array}{l}\text { MAIN STEAM PRESS TURBINE } \\
\text { INLET }\end{array}$ & $\mathrm{kg} / \mathrm{cm}^{2} \mathrm{~g}$ & 128,97 & 127,93 \\
\hline 21 & 3MAA10CP001XV1 & HP STM CHAMBER PRESS & $\mathrm{kg} / \mathrm{cm}^{2} \mathrm{~g}$ & 121,90 & 125,76 \\
\hline 22 & 3LBQ10CP001XV1 & 3-\#1 EXTRACTION PRESS/ST OUT & $\mathrm{kg} / \mathrm{cm}^{2} \mathrm{~g}$ & 33,87 & 32,69 \\
\hline 23 & 3LBQ20CP001XV1 & 3-\#2 EXTRACTION PRESS/ST OUT & $\mathrm{kg} / \mathrm{cm}^{2} \mathrm{~g}$ & 17,74 & 16,94 \\
\hline 24 & 3LBS30CP001 & 3-\#3 EXTRACTION PRESS/ST OUT & $\mathrm{kg} / \mathrm{cm}^{2} \mathrm{~g}$ & 6,71 & 7,28 \\
\hline 25 & 3LBS40CP001 & 3-\#4 EXTRACTION PRESS/ ST OUT & $\mathrm{kg} / \mathrm{cm}^{2} \mathrm{~g}$ & 2,11 & 2,39 \\
\hline 26 & 3LBS50CP001 & 3-\#5 EXTRACTION PRESS/ST OUT & $\mathrm{kg} / \mathrm{cm}^{2} \mathrm{~g}$ & $(0,18)$ & $(0,11)$ \\
\hline 27 & 3MAG10CP011XV1 & EXH PRESS 1 & $\mathrm{~kg} / \mathrm{cm}^{2} \mathrm{~g}$ & 0,08 & 0,08 \\
\hline 28 & 3LCA20CP001XV1 & 3-CP DISCHARGE PRESS. & $\mathrm{kg} / \mathrm{cm}^{2} \mathrm{~g}$ & 15,54 & 16,08 \\
\hline 29 & 3LAA10CP001XV1 & DEAERATOR INT PRESS & $\mathrm{kg} / \mathrm{cm}^{2} \mathrm{~g}$ & 6,78 & 7,20 \\
\hline 30 & 3LAB20CP001XV1 & 3-BFP DISCHARGE PRESS. & $\mathrm{kg} / \mathrm{cm}^{2} \mathrm{~g}$ & 168,62 & 169,72 \\
\hline 31 & 3НАC10СР001 & $\begin{array}{l}\text { ECON INLET FEEDWATER PRESS } \\
\text { TRANS }\end{array}$ & $\mathrm{kg} / \mathrm{cm}^{2} \mathrm{~g}$ & 139,93 & 140,12 \\
\hline 32 & 3НАН72СР001 & $\begin{array}{l}\text { SH DESUPERHEATER \#1 INLET } \\
\text { PRESS }\end{array}$ & $\mathrm{kg} / \mathrm{cm}^{2} \mathrm{~g}$ & 134,06 & 132,70 \\
\hline 33 & 3LBG10CP001 & HP AUX STM HDR PRESS & $\mathrm{kg} / \mathrm{cm}^{2} \mathrm{~g}$ & 16,80 & 17,54 \\
\hline 34 & 3LBA20CT003XV1 & MST_TURB INLET A & ${ }^{\circ} \mathrm{C}$ & 539,42 & 539,67 \\
\hline 35 & 3LBA20CT001XV1 & SUPERHEATER OUTLET TEMP & ${ }^{\circ} \mathrm{C}$ & 538,89 & 537,43 \\
\hline 36 & 3LBQ10CT001XV1 & NO.1 EXTR TEMP TURB OUTLET & ${ }^{\circ} \mathrm{C}$ & 387,74 & 376,03 \\
\hline 37 & 3LBQ20CT001XV1 & NO.2 EXTR TEMP TURB OUTLET & ${ }^{\circ} \mathrm{C}$ & 291,40 & 275,92 \\
\hline 38 & 3LBS30CT001 & 3-\#3 EXTRACTION TEMP./ ST OUT & ${ }^{\circ} \mathrm{C}$ & 207,34 & 192,74 \\
\hline 39 & 3MAG10CT001 & EXHAUST TEMP 1 & ${ }^{\circ} \mathrm{C}$ & 43,54 & 38,93 \\
\hline 40 & 3РAB50CT001XV1 & CIR WTR TEMP A-COND INLET & ${ }^{\circ} \mathrm{C}$ & 30,00 & 29,76 \\
\hline 41 & 3PAB60CT001XV1 & CIR WTR TEMP B-COND INLET & ${ }^{\circ} \mathrm{C}$ & 29,98 & 29,70 \\
\hline 42 & 3PAB51CT001XV1 & CIR WTR TEMP A-COND OUTLET & ${ }^{\circ} \mathrm{C}$ & 37,08 & 36,72 \\
\hline 43 & 3PAB61CT001XV1 & CIR WTR TEMP B-COND OUTLET & ${ }^{\circ} \mathrm{C}$ & 37,28 & 36,84 \\
\hline 44 & 3LCA10CT001XV1 & CONDENSATE TEMP & ${ }^{\circ} \mathrm{C}$ & 42,97 & 41,54 \\
\hline 45 & 3LCJ10CT001XV1 & NO.1 LPH DRAIN TEMP & ${ }^{\circ} \mathrm{C}$ & 51,54 & 50,82 \\
\hline 46 & 3LCA40CT001XV1 & COND TEMP NO.1 LPH OUTLET & ${ }^{\circ} \mathrm{C}$ & 91,33 & 93,99 \\
\hline 47 & 3LCJ20CT001XV1 & NO.2 LPH DRAIN TEMP & ${ }^{\circ} \mathrm{C}$ & 98,21 & 100,22 \\
\hline 48 & 3LCA50CT001XV1 & COND TEMP DEA INLET & ${ }^{\circ} \mathrm{C}$ & 130,32 & 134,86 \\
\hline 49 & 3LAA10CT001XV1 & FW TEMP DEA STRG TANK & ${ }^{\circ} \mathrm{C}$ & 166,69 & 163,69 \\
\hline 50 & 3LAB20CT001XV1 & BFP DISCH TEMP & ${ }^{\circ} \mathrm{C}$ & 169,59 & 173,74 \\
\hline 51 & 3LCH40CT001XV1 & NO.4 HPH DRAIN TEMP & ${ }^{\circ} \mathrm{C}$ & 178,74 & 182,46 \\
\hline 52 & 3LAB30CT001XV1 & NO.4 HPH HTR OUTLET TEMP & ${ }^{\circ} \mathrm{C}$ & 202,44 & 203,04 \\
\hline 53 & 3LCH50CT001XV1 & NO.5 HPH DRAIN TEMP & ${ }^{\circ} \mathrm{C}$ & 209,48 & 208,23 \\
\hline 54 & 3LAB40CT001XV1 & NO.5 HPH HTR OUTLET TEMP & ${ }^{\circ} \mathrm{C}$ & 238,52 & 237,88 \\
\hline 55 & 3НАC10СТ001 & $\begin{array}{l}\text { U3 ECON INLET FEEDWATER } \\
\text { TEMP }\end{array}$ & ${ }^{\circ} \mathrm{C}$ & 239,80 & 236,97 \\
\hline 56 & 3HAH72CT002XV1 & DESUPERHEATER \#1 INLET TEMP & ${ }^{\circ} \mathrm{C}$ & 466,94 & 467,77 \\
\hline 57 & 3LBG10CT001 & HP AUX STEAM TEMP & ${ }^{\circ} \mathrm{C}$ & 292,01 & 296,08 \\
\hline 58 & 3LCP11CT001XV1 & MAKE UP WATER TEMP & ${ }^{\circ} \mathrm{C}$ & 32,39 & 34,22 \\
\hline
\end{tabular}




\section{KILAT}

Vol. 10, No. 1, April 2021, P-ISSN 2089-1245, E-ISSN 2655-4925

DOI: https://doi.org/10.33322/kilat.v10i1.1178

\section{HASIL DAN PEMBAHASAN}

Dari data inputan parameter performance test di atas dapat dihitung efisiensi isentropis turbin uap pada beban $90 \mathrm{MW}$. Data inputan komissioning pada tabel $1 \mathrm{di}$ atas harus dibuat interpolasi terlebih dahulu supaya relevan dengan beban 90 MW kondisi komissioning. Kondisi turbin selama beroperasi harus pada mode normal. Dan selama proses pengambilan data performance test, unit harus dijaga dalam kondisi aliran (flow) yang stabil, tekanan dan temperaturnya, sehingga diperlukan setidaknya waktu selama 1 jam sebelum mulai untuk membuat kondisi ini. Proses isolasi keakuratan hasil pengujian tergantung pada isolasi dari sistem. Aliran-aliran yang tidak diperlukan harus diisolasi dari sistem [11]. Tabel 2 di bawah ini merupakan hasil perhitungan efisiensi isentropis pada performance test beban $90 \mathrm{MW}$ berbanding dengan data komissioning.

Tabel 2. Analisa Perbandingan Perhitungan Data Performance test dan Komissioning

\begin{tabular}{|l|c|c|c|c|}
\hline \multirow{2}{*}{ Parameter } & \multirow{2}{*}{ Simbol } & \multirow{2}{*}{ Unit } & \multicolumn{2}{c|}{ HP Turbine } \\
\cline { 3 - 5 } & & & Commisioning & Performance test \\
\hline Inlet & & & & 539,18 \\
\hline Temperature & $\mathrm{T}_{\text {in }}$ & ${ }^{\circ} \mathrm{C}$ & $3.441,14$ & 539,42 \\
\hline Enthalphy & $\mathrm{H}_{\text {in }}$ & $\mathrm{kJ} / \mathrm{kg}$ & 6,57 & 3444,45 \\
\hline Entropi & $\mathrm{S}_{\text {in }}$ & $\mathrm{kJ} / \mathrm{kg}\left({ }^{0} \mathrm{C}\right)$ & & 6,58 \\
\hline Outlet & & & 0,07 & 0,08 \\
\hline Pressure & $\mathrm{P}_{\text {out }}$ & $\mathrm{bar}(\mathrm{a})$ & 40,04 & 43,54 \\
\hline Temperature & $\mathrm{T}_{\text {out }}$ & ${ }^{\circ} \mathrm{C}$ & $2.208,42$ & 2277,01 \\
\hline Saturated Enthalphy & $\mathrm{HLP}_{\text {out }}$ & $\mathrm{kJ} / \mathrm{kg}$ & $1.232,72$ & 1167,44 \\
\hline Kerja Turbin Aktual & $\Delta \mathrm{P}_{\text {aktual }}$ & $\mathrm{kJ} / \mathrm{kg}$ & $1.394,41$ & 1384,03 \\
\hline Kerja Turbin Ideal & $\Delta \mathrm{HP}_{\text {isentropis }}$ & $\mathrm{kJ} / \mathrm{kg}$ & 161,69 & 216,60 \\
\hline Rugi-Rugi Turbin & $\mathrm{L}_{\mathrm{T}}$ & $\mathrm{kJ} / \mathrm{kg}$ & 0,52 & 0,69 \\
\hline Selisih Entropi & $\Delta \mathrm{S}_{\mathrm{l}}$ & $\mathrm{kJ} / \mathrm{kg}\left({ }^{0} \mathrm{C}\right)$ & 88,40 & 84,35 \\
\hline Efisiensi Turbin & $\eta_{\text {turbin }}$ & ${ }^{*} \%$ & & \\
\hline
\end{tabular}

Dari data hasil perhitungan pada tabel 2 di atas terlihat bahwa untuk tekanan keluar turbin $\mathrm{P}_{\text {out }}$ yang mana merupakan tekanan vakum kondensor dalam satuan bar(a) terdapat penurunan tekanan vakum atau kenaikan tekanan sebesar 0,01 bar(a) dibanding data komissioning, hal ini berpengaruh pada temperatur exhaust turbin $\mathrm{T}_{\text {out }}$ yang mengalami kenaikan sebesar $3,5{ }^{\circ} \mathrm{C}$ dibanding data komissioning.

Kenaikan temperatur exhaust turbin ini dikarenakan kemungkinan karena kinerja kondensor dan sistem vakum ejector yang sudah tidak optimal. Kondensor merupakan alat penukar kalor yang berfungsi untuk mengkondensasikan uap keluaran turbin. Kinerja dari suatu kondensor dapat dilihat dari nilai efektivitasnya. Efektivitas kondensor dipengaruhi oleh beberapa faktor antara lain aliran steam dan aliran cooling water [12]. Penurunan tekanan vakum di dalam kondensor saat proses kondensasi memberikan perbedaan entalpi yang semakin besar pada turbin [13]. Kondisi aliran uap di dalam turbin merupakan parameter yang penting untuk dikaji lebih lanjut. Parameter uap pada saluran masuk bagian uji sesuai dengan kondisi riil di bagian tekanan rendah turbin uap [14]. Kinerja kondensor diketahui dari perhitumgan efektivitas kondensor dengan parameter laju massa dan 
enthalpy uap keluaran turbin, kondensat, dan air pendingin. Oleh karenanya, perlu perbandingan antara efektivitas data aktual dengan data desain, sehingga diketahui seberapa baik pengoperasian kondensor [15].

Gambar 5 di bawah ini menjelaskan tentang perbandingan kerja turbin aktual dan ideal (isentropis) hasil perhitungan data performance test dan komissioning.

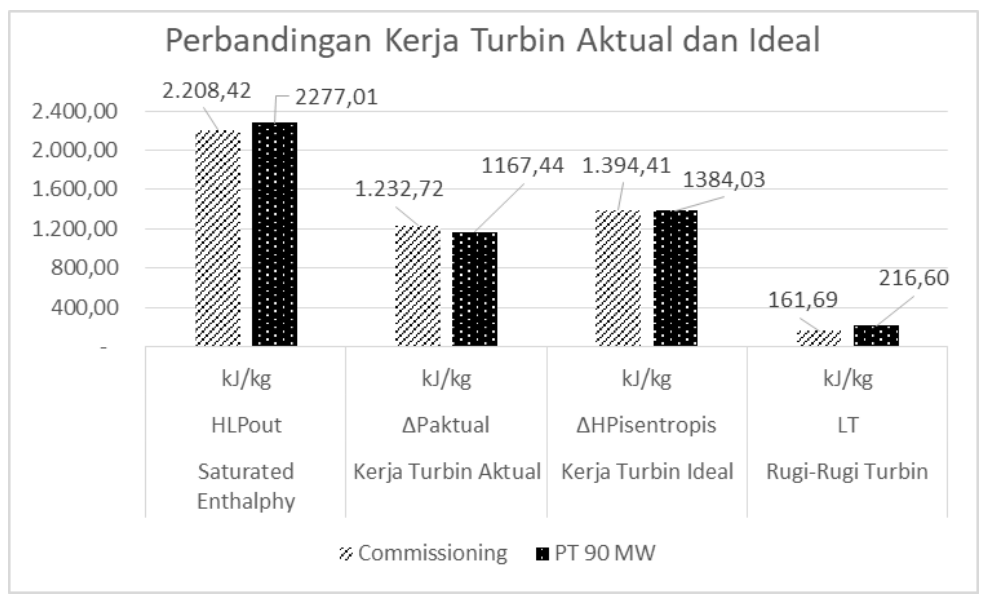

Gambar 5. Grafik Perbandingan Kerja Turbin Aktual dan Ideal

\section{KESIMPULAN DAN SARAN}

Dari hasil penelitian yang dilakukan dapat diambil kesimpulan bahwa terdapat penurunan kerja turbin aktual cukup signifikan dibanding data komissioning yaitu sebesar 65,28 kJ/kg dimana data komissioning menunjukan nilai $1232,72 \mathrm{~kJ} / \mathrm{kg}$ sedangkan data performance test menunjukan nilai $1167,44 \mathrm{~kJ} / \mathrm{kg}$. Padahal kalo kita lihat bahwa kerja turbin ideal pada saat komissioning dan performance test tidak jauh berbeda dimana data komissinong menunjukkan nilai $1394,41 \mathrm{~kJ} / \mathrm{kg}$ sedangkan data performance test menunjukkan nilai 1384,03 kJ/kg. Penurunan kerja turbin aktual ini tentunya mempengaruhi efisiensi isentropis turbin uap tersebut, berdasarkan hasil perhitungan pada tabel 2 didapatkan penurunan efisiensi isentropis turbin sebesar 4,05\% dimana data komissioning menunjukkan nilai $88,4 \%$ sedangkan data performance test menunjukkan nilai $84,35 \%$. Hal ini juga mengindikasikan adanya kenaikan rugi-rugi turbin yang terjadi dibandingkan saat komissioning yaitu sebesar 54,91 kJ/kg seperti ditunjukkan pada gambar 5 .

Kenaikan rugi-rugi turbin ini kemungkinan besar dipengaruhi oleh kenaikan tekanan oulet turbin $\mathrm{P}_{\text {out }}$ seperti yang ditunjukkan pada tabel 2. Hal ini mengindikasikan adanya permasalahan pada sistem vakum dan juga kondensor. Sistem vakum yang terintegrasi dengan kondensor sangat mungkin terjadi masalah yang menyebabkan terjadinya perubahan kondisi exhaust steam turbin. Berdasarkan penelitian yang dilakukan oleh V. Apriyanti et al [13], diperkirakan, penurunan 0,01 bar tekanan kondensor akan mampu menghasilkan 1,5-1,6\% energi listrik dari kapasitas pembangkit. Begitu juga sebaliknya, jika terjadi kenaikan tekanan kondensor maka energi listrik yang dihasilkan akan semakin berkurang. energi listrik yang hilang dapat setara dengan suatu PLTP berkapasitas 2 MW. Kandungan gas tak terkondensasi (noncondensable gas-NCG) dan temperatur air pendingin menjadi variabel yang berpengaruh terhadap kinerja kondensor. 


\section{KILAT}

Vol. 10, No. 1, April 2021, P-ISSN 2089-1245, E-ISSN 2655-4925

DOI: https://doi.org/10.33322/kilat.v10i1.1178

Saran yang bisa diberikan dari hasil penelitian ini adalah tindakan perbaikan sistem vakum yang ada sehingga dapat mengembalikan kondisi vakum pada saat komissioning, hal ini penting karena dengan kenaikan tekanan exhaust turbin sedikit saja maka kerja turbin aktual menjadi jauh berbeda. Kemudian juga perbaikan sistem kondensor yang meliputi pengecekan seluruh bagian tube kondensor dan analisa performa kondesor yang merupakan perbandingan antara efektivitas data aktual dengan data desain, sehingga diketahui seberapa baik pengoperasian kondensor dan juga sistem pendinginan kondensor itu sendiri yang dipengaruhi oleh sistem pendinginan utama dari sistem Circulating Water Pump (CWP) dan juga kualitas air pendingin utama yang digunakan.

\section{UCAPAN TERIMA KASIH}

Penulis mengucapkan terima kasih yang sebesar-besarnya kepada rekan-rekan dari PT PLN (Persero) UPK Tarahan yang telah memberi dukungan berupa data-data parameter performance test dan komissioning yang membantu pelaksanaan penelitian ini dan juga kepada para pihak yang tidak bisa disebutkan satu per satu yang telah mendukung hingga tahap akhir penulisan artikel ilmiah ini.

\section{DAFTAR PUSTAKA}

[1] A. S. Karakurt and Ü. Güneş, "Performance analysis of a steam turbine power plant at part load conditions," J. Therm. Eng., vol. 3, no. 2, pp. 1121-1128, 2017, doi: 10.18186/thermal.298611.

[2] T. M. Anggraini, A. S. Sanjaya, and R. A. Wikanswasto, "Perhitungan Asr dan Efisiensi Internal Steam Turbine (Back Pressure)," J. Chemurg., 2019, doi: 10.30872/cmg.v2i2.2231.

[3] E. Yohana and R. Romadhon, "Analisa Efisiensi Isentropik dan Exergy Destruction Pada Turbin Uap Sistem Pembangkit Listrik Tenaga Gas dan Uap," ROTASI, 2017, doi: 10.14710/rotasi.19.3.134-138.

[4] S. Satiti, "Analisis Performa PLTU Versus Variasi Beban pada Turbin Uap Menggunakan Software Cycle Tempo," 2015.

[5] T. Tanuma, Advances in steam turbines for modern power plants. 2016.

[6] Y. R. Febriansyah, "Analisis Termodinamika pada PLTU (Pembangkit Listrik Tenaga Uap) Terhadap Pembebanan Operasi di PT. X," Jur. Tek. Mesin, Inst. Sains Teknol. AKPRIND Yogyakarta, 2018.

[7] H. Abbas, J. Jamaluddin, M. Arif, and A. Amiruddin, "ANALISA PEMBANGKIT TENAGA LISTRIK DENGAN TENAGA UAP DI PLTU," ILTEK J. Teknol., 2019, doi: 10.47398/iltek.v14i01.362.

[8] “ASME PTC 6-2004 Steam Turbine Performance Test Code.pdf.".

[9] Sunarwo and Supriyo, "Analisa Heat Rate Pada Turbin Uap Berdasarkan Performance Test Pltu Tanjung Jati B Unit 3,” Tek. Energi, 2015.

[10] R. Apriandi and A. Mursadin, "ANALISIS KINERJA TURBIN UAP BERDASARKAN PERFORMANCE TEST PLTU PT. INDOCEMENT P-12 TARJUN,” Sci. J. Mech. Eng. Kinemat., 2016, doi: 10.20527/sjmekinematika.v1i1.26.

[11] M. Sagaf and S. Alim, "PREDIKSI KENAIKAN HEAT RATE TURBIN UAP PADA PEMBANGKIT LISTRIK BERKAPASITAS 660 MW,” J. Ilm. MOMENTUM, 2019, doi: 10.36499/jim.v15i2.3075.

[12] E. Yohana, B. Farizki, N. Sinaga, M. E. Julianto, and I. Hartati, "Analisis Pengaruh Temperatur dan Laju Aliran Massa Cooling Water Terhadap Efektivitas Kondensor di PT. Geo Dipa Energi Unit Dieng,” ROTASI, 2019, doi: 10.14710/rotasi.21.3.155-159. 
[13] V. Apriyanti, A. D. Pasek, Abdurrachim, W. Adriansyah, and R. Abdurrahman, "Perancangan Perangkat Eksperimen Kondensasi Kontak Langsung dengan Keberadaan Non Condensable Gas," Proceeding Semin. Nas. Tah. Tek. Mesin XIV (SNTTM XIV), 2015.

[14] S. Dykas, M. Majkut, M. Strozik, and K. Smołka, "Experimental study of condensing steam flow in nozzles and linear blade cascade," Int. J. Heat Mass Transf., 2015, doi: 10.1016/j.ijheatmasstransfer.2014.09.010.

[15] A. Rosyada, A. R. Anhar, and I. Silanegara, "Analisis Kinerja Kondensor Unit Iv Sebelum Dan Sesudah Overhaul," POLITEKNOLOGI. 2017. 